\title{
CAN APPLICATION TECHNOLOGY HELP TO MANAGE PESTICIDE RESISTANCE?
}

\author{
J-P. PRAAT ${ }^{1}$, D. MANKTELOW ${ }^{2}$, D.M. SUCKLING ${ }^{3}$ and J. MABER ${ }^{1}$ \\ ${ }^{1}$ Agrichemical Group, Lincoln Technology, Private Bag 3062, Hamilton \\ ${ }^{2}$ HortResearch, Private Bag 1401, Havelock North \\ ${ }^{3}$ HortResearch, PO Box 51, Lincoln
}

\begin{abstract}
Low and/or uneven spray deposits are frequently implicated in failure to control pests or diseases, but little is known about the resistance selection pressures imposed by such deposits. Overdosing represents inefficient pesticide use and may select for development of high levels of single gene resistance. Pest or disease exposure to low pesticide doses may select for development of polygenic resistance. Current application techniques are inefficient and this, coupled with trends to lower pesticide dose rates, will tend to increase pest and disease exposure to low pesticide doses. This paper highlights the spray deposit variability observed in New Zealand fruit crops and discusses this in the context of resistance management and opportunities to improve agrichemical targetting.
\end{abstract}

Keywords: Pesticide application, pesticide resistance, apple, grape

\section{INTRODUCTION}

Pesticide deposit variability may be important in pesticide resistance development. However, there has been little quantitative work to determine the impact of different spray application methods and resulting deposits on selecting for resistance. Indeed, in most instances effects of different spray deposits resulting from different pesticide application technologies on insect mortality or disease suppression is not well understood.

Spatial patterns of pesticide use and the scale of gene flow of a population under selection are critical determinants of whether or not resistance develops (Shaw 1992). If the area under treatment is small relative to the level of gene flow, then resistance development will be retarded. Levels of pesticide resistance have been correlated with spatial patterns of pesticide use in a number of cases, although the scale of variation in resistance, and by implication of selection pressure, has usually been at the orchard or farm level. Examples include insects on coffee (Brun et al. 1990), apples (Suckling et al. 1984; Knight and Hull 1990), and cotton (Hollingsworth et al. 1994). However, it is increasingly being realised that our assumptions about the impact of the role of dispersal and gene flow on delaying reistance may need to be examined more carefully (Tabashnik et al. 1992). There has been little consideration in the literature of the influence of spatial variation in pesticide deposition within the canopy on selection for resistance. This paper highlights the variability of agrichemical spray deposits observed within New Zealand fruit crops, and discusses this situation in the context of resistance prevention and management.

\section{PESTICIDE APPLICATION IN RESISTANCEMANAGEMENT STRATEGIES}

A frequent assumption underlying pesticide use is that the application technique used achieves an even and effective dose on the target. In reality, most current pesticide application techniques are relatively inefficient and chemical deposits vary greatly within and between canopies. Deposit variability problems are reflected in the statement "NOTE: CONTROL FAILURE DOES NOT ALWAYS IMPLY RESISTANCE", which appears in the New Zealand resistance management strategies (Prince et al. 1989). 
Some of the New Zealand pesticide resistance management strategies (Elliot et al. 1988; Prince et al. 1989; Suckling 1996) specifically refer to pesticide application issues, but none fully address the results of current practices and trends in pesticide application and use. Many of these resistance management strategies emphasise the need to adhere to chemical label rates. However, none of the management strategies address variability in the doses achieved with different spraying techniques and spray programmes. For example, miticide and leafroller resistance management strategies (Prince et al. 1989; Chapman 1996; Suckling 1996) contain some specific recommendations relating to pesticide application, namely; "ensure miticide applications are correctly timed and spray coverage is thorough including the undersides of leaves" and "use correct application procedures, observing correct tractor speeds and spraying conditions to obtain good insecticide coverage". The leafroller strategy also states "calibrate sprayers at least once per season" and emphasises the need to manage tree form to assist spray penetration and coverage.

Spray coverage is influenced by many factors including travel speed, droplet sizes, canopy form, canopy density, weather at the time of application and basic sprayer performance. Unfortunately, the definition of good coverage is extremely loose and coverage requirements vary with pest problems and pesticide modes of action and formulation. For example, insecticides with high vapour pressure (e.g. some organophosphates) that work with contact and feeding toxicity require less precision in deposition than insecticides which rely only on feeding, such as Bacillus thuringiensis. In the latter case, a more even deposit achieved using a surfactant can produce better results (Suckling et al. 1993).

\section{SPRAY DEPOSIT VARIABILITY}

Selection pressure for resistance will vary with different pesticides and pest situations. The impact of many biological and operational factors on resistance has been under investigation for some time (Georghiou and Taylor 1977). The New Zealand resistance management strategies all emphasise a need to use pesticides at label rates. However, both overdosing and underdosing from uneven spray deposits may, in at least some situations, impose significant resistance selection pressures. Where insects are mobile and do not respond behaviourally to variable pesticide deposits, this uneveness may be less critical, since they will tend to pick up an average dose. For pests which detect and avoid deposits of products with low vapour pressure (e.g. pyrethoids), or less mobile pests and most diseases, this variation is more likely to be important.

Deposits from airblast spraying of New Zealand apples vary greatly between inner and upper part of trees, which are relatively difficult to spray and the more easily sprayed outer parts of trees. Table 1 contains deposit data from four different apple training systems. The trees were sprayed using a standard, axial-fan airblast sprayer fitted with Spraying Systems D Series hollow cone nozzles. TX nozzles were used to achieve $5 X$ concentrate of dilute volumes. Deposits were determined by spectrophotometry of a food dye tracer (Hexagran Brilliant Blue, Bayer dyestuffs) that was washed off bulked, five-leaf samples. Spray volumes were adjusted in relation to canopy volume to just achieve run-off in each training system. Deposits were standardised to an application rate of one kilogram of tracer per hectare to allow deposits to be compared between canopies. Samples were collected from 10 to 15 different sample zones from within each of four replicate trees per canopy.

The data in Table 1 are typical of deposits which provide acceptable pest and disease control in commercial New Zealand apple spray programmes. The variations observed are largely due to the need to overdose the canopy close to the sprayer in order to achieve acceptable deposits on obscured or distant areas of the canopy. The variability of spray deposit described in Table 1 (CVs from 25.7 to $56.7 \%$ ) is consistent with European reports which commonly list CVs ranging from 40-80\% (Koch and Wießer 1994). The degree of deposit variability which will compromise pest or disease control is not well defined. The two-to-seven-fold variation in withincanopy deposits presented in Table 1 resulted even with dual surface washings of 
bulked leaf samples, averaged from tree replicates. Variability within individual trees and between individual leaves was at least twice as great (data not presented). Smaller scale deposit variations can be even higher, for example, where good coverage is obtained on one leaf surface, poor coverage is often obtained on the other (Greaves et al. 1992). The deposit variations observed are likely to be important in resistance selection if they tend to be repeated over multiple spray applications. Similar concerns have been raised in Germany (Koch and Spieles 1992).

TABLE 1: Leaf spray deposit variability observed within and between four apple training systems ${ }^{1}$ in New Zealand.

\begin{tabular}{|c|c|c|c|c|c|c|c|c|}
\hline \multirow{2}{*}{$\begin{array}{c}\text { Royal Gala apple } \\
\text { training system } \\
\text { (Spray volume/ } \\
\text { No. of sample } \\
\text { zones) }\end{array}$} & \multicolumn{2}{|c|}{$\begin{array}{c}\text { Lowest } \\
\text { deposit } \\
\left(\mu \mathrm{g} / \mathrm{cm}^{2}\right)\end{array}$} & \multicolumn{2}{|c|}{$\begin{array}{c}\text { Highest } \\
\text { deposit } \\
\left(\mu \mathrm{g} / \mathrm{cm}^{2}\right)\end{array}$} & \multicolumn{2}{|c|}{$\begin{array}{c}\text { Mean } \\
\text { deposit } \\
\left(\mu \mathrm{g} / \mathrm{cm}^{2}\right)\end{array}$} & \multicolumn{2}{|c|}{$\begin{array}{l}\text { Deposit } \\
\mathrm{CV}^{2} \\
(\%)\end{array}$} \\
\hline & Dilute & Conc. ${ }^{3}$ & Dilute & Conc. & Dilute & Conc. & Dilute & Conc. \\
\hline $\begin{array}{c}\text { Dwarf axis } \\
1100 / 10\end{array}$ & 1.5 & 2.4 & 4.7 & 5.7 & 3.6 & 3.9 & 42.8 & 25.7 \\
\hline $\begin{array}{c}\text { Slender spindle } \\
2300 / 12\end{array}$ & 0.9 & 0.9 & 3.4 & 5.1 & 2.0 & 2.3 & 38.5 & 52.7 \\
\hline $\begin{array}{c}\text { Traditional } \\
\text { centre leader } \\
3000 / 15\end{array}$ & 1.0 & 0.8 & 3.4 & 5.5 & 1.8 & 2.5 & 27.8 & 38.7 \\
\hline $\begin{array}{l}\text { Traditional } \\
\text { multileader } \\
2500 / 15\end{array}$ & 0.8 & 1.2 & 2.6 & 4.2 & 2.2 & 2.6 & 34.2 & 56.7 \\
\hline Highest:lowest ratio & & & & & 2.0 & 1.7 & & \\
\hline
\end{tabular}

${ }^{1}$ See text for treatment details

${ }^{2} \mathrm{CV}=$ Coefficient of variation

${ }^{3} \mathrm{Conc}=$ Concentrate spray $(5 \mathrm{X}$ concentration of dilute spray $)$

The distribution of spray deposits are greatly influenced by application technique. For example, Maber and Praat (1995) observed that deposits from a conventional axial-fan airblast sprayer favoured lower surfaces of apple leaves, while deposits from a tower sprayer favoured upper leaf surfaces. Deposit variability on leaf surfaces can be important when pests or diseases tend to favour one surface over another. For example, Suckling (1985) observed that early stage leafrollers favour the undersurfaces of apple leaves, and that insecticide dose rates for leafroller control had to be increased two to three fold for a spray application technique that gave lower insecticide deposits on leaf under-surfaces compared with one giving even leaf surface deposits.

It is generally accepted that pesticide residues on plant surfaces will be redistributed to some extent by mechanisms including vapour phase activity, systemic movement, rewetting of the plant and/or dispersion along concentration gradients. Deposit redistribution will help alleviate problems associated with uneven initial deposits and may be an important factor in control of wet weather diseases with protectant fungicides. Protectant fungicide deposit redistribution during surface wetting events should tend to even the chemical dose to which spores are exposed. If this is the case, resistance selection pressures will be generally lower than those presented by uneven initial deposits.

An extreme example of spray deposit variations leading to resistance problems was highlighted with endosulfan resistance in the coffee berry borer, Hypothenemus hampei (Brun and Suckling 1992). This is probably an example of "application technology-induced pesticide resistance"; a large truck-based cannon sprayer was used to spray across a coffee plantation from one side, with a resulting dose gradient 
across the field (Parkin et al. 1992). It seems likely that the high deposits achieved close to the sprayer selected heavily for resistant insects, which was borne out by bioassays. A gradient in pesticide selection in this manner would explain the high resistance frequency seen in beetles present at the roadside (Brun and Suckling 1992).

Serious dicarboximide fungicide resistance problems with Botrytis cinerea are currently being experienced by the New Zealand grape industry. The use of these fungicides is restricted to the period immediately before harvest. Grape bunches at this stage present a difficult spraying target. Bunch coverage obtained at harvest from seven different grape sprayers was examined by Praat and Manktelow in 1994 (unpublished). There was a greater than three-fold variation in mean bunch deposit, and none of the machines examined gave coverage considered adequate for effective disease control. The large variations in both average dose and coverage observed could present a major selection pressure for disease resistance. A lot of work to improve evenness of deposits has been done with grapevines in Germany and some useful information has resulted (Bäcker and Brendel 1989). However, the effective adoption of new grape pesticide application technologies has been slow in New Zealand.

\section{PESTICIDE DOSE}

There are strong trends in New Zealand and around the world for growers to reduce pesticide use. In some cases reductions are being achieved through use of technology to target pesticide application to specific areas rather than make blanket pesticide applications. Different application systems that target pesticides to limited areas include: 1) combined Global Positioning Systems and Geographical Information Systems (GPS/GIS) that map weeds and target herbicide applications to specific areas (Anon. 1995), 2) sensors to detect presence of the crop canopy or weed and only spray when the target is present e.g. using infra red sensors (Bäcker et al. 1995; Nitsch et al. 1991) and 3) tunnel and shielded sprayers that recapture and recycle over-spray that would normally be lost. Targeted application should reduce pesticide resistance selection over that imposed by blanket spraying, if only because a smaller proportion of a pest population will be exposed to the selection pressure. In many cases, pesticide use reductions are being made by simply reducing active ingredient rates in blanket spraying operations. There is potential to safely do so, provided application practices and/or equipment are made more efficient. Examples can be seen with the introduction of air-assisted boom sprayers in field crops, tower sprayers in tree crops and tunnel sprayers in hedgerow crops.

Apple spray programmes using chemical dose rates at $25 \%$ or less of standard label rates, applied with various controlled droplet application (CDA) systems, have been used in England for some time (Cross and Berrie 1990). However, there must be a level at which improved spraying efficiency cannot compensate for reduced dose and a trend for greater pest survival with decreasing dose rate has been observed (Cross and Berrie 1990; Koch and Spieles 1992). In such cases, reduced pesticide dose rates could increase selection pressure for polygenic resistance. In another approach, organo-silicone surfactants in half-rate apple insecticide programmes achieved similar control to full-rate programmes, probably as a result of improved eveness of coverage (Stevens et al. 1994). Selection pressure for resistance from the half-rate programme should be unchanged, since control levels were the same.

Pesticide rates and application practices need to reflect changes in crop training systems and stages of development. For example, mean chemical deposits achieved when different New Zealand apple canopies were sprayed to run-off were found to vary by over a factor of two (Table 1). Experiments with calibration systems in New Zealand have shown that average spray deposits on leaves can be predicted on the basis of canopy volumes (as opposed to ground area) (Manktelow and Praat unpublished).

\section{CONCLUSIONS}

Current New Zealand apple orchard and vineyard spraying practices generally result in highly variable spray deposits. Pesticide application technology is an essential component of pest and disease management, which has not received the attention it 
requires. Failure to achieve appropriate pesticide dosage results in poor pest and disease control and may contribute to the development of pesticide resistance. The definition of application requirements needs to be better addressed in strategies for pest and disease control, and for resistance management. There are major gaps in our knowledge of the interaction between pesticides and their targets at the level of the canopy and foliage surface, especially in relation to selection for resistance. Improvements in the accuracy and efficiency of spray applications which result in more even and/or better targeted spray deposits should help to ensure control, while reducing selection for resistance. Improvements can be achieved by adopting new pesticide application technologies and matching these to specific crop, pest and pesticide situations.

\section{REFERENCES}

Anonymous, 1995. Precision Farming. Silsoe Link, Issue 9, Summer, 1995 p12.

Bäcker, G. and Brendel, G., 1989. Gebläsebauarten im Pflanzenschultz - Biologisdhe Leistung und Umweltvertraglichkeit.Das Deutsche Weinmagazin May 1989, 13/ 5: 506-512.

Bäcker, G., Westphal, O. and Göhlich. H., 1995. Infrarot-Augen suern die Düsen. Das Deutsche Weinmagazin May, 1995 15/27:24-28.

Brun, L.O., Marcillaud, C., Gaudichon, V. and Suckling, D.M., 1990. Monitoring endosulfan and lindane resistance in the coffee berry borer Hypothenemus hampei (Coleoptera: Scolytidae) in New Caledonia. Bull. Ent. Res. 80: 129-135.

Brun L.O. and Suckling, D.M., 1992. Field selection for resistance in the coffee berry borer (Coleoptera: Scolytidae) in New Caledonia. J. Econ. Entomol. 85: 325-334.

Chapman, R.B., 1996. Spider mites resistance management strategy. Pp 177-183 In: Pesticide Resistance: Prevention and Management. G.W. Bourdôt and D.M. Suckling (Eds). New Zealand Plant Protection Society, Christchurch.

Cross, J.V. and Berrie, A.M., 1990. Efficacy of reduced volume and reduced dose rate spray programmes in apple orchards. Crop Prot. 9: 207-217.

Elliot, G.S., Moore, M.S. and Wearing, C.H., 1988. The New Zealand Committee on Pesticide Resistance 1988 Summary. Proc. 41st N.Z. Weed and Pest Control Conf::288-292.

Georghiou, G.P. and Taylor, C.E., 1977. Operational influences in the evolution of insecticide resistance. J. Econ. Entomol. 70: 653-658.

Greaves, A.J., Tompkins, A.R., Malcolm, C.P., Upsdell, M.P., Thomson, C. and Wilson, D.J., 1992. Distribution and decay of phosmet residues in the canopy of “T-bar" trellised kiwifruit. N.Z. J. Crop Hort. Sci. 20: 313-318.

Hollingsworth, R.G., Tabashnik, B.E., Ullman, D.E., Johnson, M.W. and Messing, R., 1994. Resistance of Aphis gossypii (Homoptera: Aphididae) to insecticides in Hawaii: spatial patterns and relation to insecticide use.J. Econ. Entomol. 87: 293300.

Knight, A.L. and Hull, L.A., 1990. Areawide patterns of azinphosmethyl resistance in adult male Playnota idaeusalis (Lepidoptera: Tortricidae) in Southcentral Pennsylvannia. J. Econ. Entomol. 83: 1194-1200.

Koch, H. and Weißer, P., 1994. Variablity of initial deposits of pesticides in orchards. Zeitschrift fur Plfanzenkrankheiten und Pflanzenschutz.(Journal of Plant Diseases and Protection) 101(6):634-640.

Koch, H. and Spieles, M., 1992. Distribution of spray deposit and powdery mildew (Erysiphe graminisf. sp. tritici) in a wheat crop.Zeitschrift fur Plfanzenkrankheiten und Pflanzenschutz (Journal of Plant Diseases and Protection) 99(3):274-303.

Maber, J. and Praat, J-P., 1995. Fruit tree crop spray application technology. Final project report (Technology for Business Growth). May 1995. 39pp.

Nitsch, B.B., Von Bargen, K., Meyer, G.E. and Mortensen, D.A., 1991. Visible and near infrared plant, soil and crop residue reflectivity for weed sensor design. Paper - American Society of Agricultural Engineers. No 91-3006, 31pp.

Parkin, C.S., Brun, L.O., and Suckling, D.M., 1992. Spray deposition in relation to endolsulfan resistance in coffee berry borer (Hypothemus hampei Coleoptera: Scolytidae) in New Caledonia. Crop Prot. 11: 213-220. 
Prince, R.W., Moore, M.S. and Wearing, C.H., 1989. The New Zealand committee on pesticide resistance 1989 summary.Proc. 42 nd N.Z. Weed and Pest Control Conf: 278-292.

Shaw, M.W., 1992. How does spatial structure in populations affect the spread of fungicide resistance? Pp 136-147 In: Resistance '91: Achievements and Developments in Combating Pesticide Resistance. I. Denholm, A.L. Devonshire and D.W. Hollomon (Eds). Elsevier Applied Science, London.

Stevens, P.J.G., Walker, J.T.S., Shaw, P.W. and Suckling, D.M., 1994. Organosilicone surfactants: Tools for horticultural crop protection. Proc. Brighton Crop Prot. Conf: $755-760$.

Suckling, D.M., 1985. Etude de la rémanance de l'aziphos-méthyl utilisé contre Epiphyas postvittanaWalker(Lepid.: Tortricidae) en NouvelleZélande.Agronomie 5: 893-898.

Suckling, D.M., 1996. Leafroller insecticide resistance management strategy. Pp 168171 In: Pesticide Resistance: Prevention and Management. G.W. Bourdôt and D.M. Suckling (Eds). New Zealand Plant Protection Society, Christchurch.

Suckling, D.M., Shaw, P.W. and Brown, B., 1993. Efficacy of Bt, carbaryl and pyrethrum against lightbrown apple moth. Proc. 46th N.Z. Plant Prot. Conf.: 141145.

Suckling, D.M., Wearing, C.H., Thomas, W.P., Penman, D.R. and Chapman, R.B., 1984. Insecticide resistance in the lightbrown apple moth: a case for resistance management. Proc. 37th Weed Pest Cont. Conf:: 248-252.

Tabashnik, B.E., Rosenheim, J.A., and Caprio, M.A., 1992. What do we really know about management of insecticide resistance? Pp124-135 In: Resistance '91: Achievements and Developments in Combating Pesticide Resistance. I. Denholm, A.L. Devonshire and D.W. Hollomon (Eds). Elsevier Applied Science, London. 